\title{
Plasticity of the melanocortin system: determinants and possible consequences on food intake
}

\author{
Danaé Nuzzaci, Amélie Laderrière, Aleth Lemoine, Emmanuelle Nédélec, \\ Luc Pénicaud, Caroline Rigault and Alexandre Benani*
}

Center for Taste and Feeding Behaviour, CNRS (UMR6265), INRA (UMR1324), Université de Bourgogne-Franche Comté, Dijon, France

\section{OPEN ACCESS}

Edited by:

Marc Claret,

Institut d'Investigacions Biomèdiques August Pi i Sunyer, Spain

Reviewed by:

Julie A. Chowen,

Hospital Infantil Universitario Niño

Jesús, Spain

Cristina García Cáceres,

Technische Universität München,

Germany

${ }^{*}$ Correspondence:

Alexandre Benani,

Centre des Sciences du Goût et de

l'Alimentation (CSGA), CNRS

(UMR6265), INRA (UMR1324),

Université de Bourgogne-Franche Comté, 9E Boulevard Jeanne d'Arc,

Dijon 21000, France

alexandre.benani@u-bourgogne.fr

Specialty section:

This article was submitted to Neuroendocrine Science, a section of the journal Frontiers in Endocrinology

Received: 20 July 2015

Accepted: 31 August 2015

Published: 14 September 2015

Citation:

Nuzzaci D, Laderrière A, Lemoine $A$, Nédélec E, Pénicaud L, Rigault C and Benani A (2015) Plasticity of the melanocortin system: determinants and possible consequences on food

intake.

Front. Endocrinol. 6:143. doi: 10.3389/fendo.2015.00143
The melanocortin system is one of the most important neuronal pathways involved in the regulation of food intake and is probably the best characterized. Agouti-related peptide (AgRP) and proopiomelanocortin (POMC) expressing neurons located in the arcuate nucleus of the hypothalamus are the key elements of this system. These two neuronal populations are sensitive to circulating molecules and receive many excitatory and inhibitory inputs from various brain areas. According to sensory and metabolic information they integrate, these neurons control different aspects of feeding behavior and orchestrate autonomic responses aimed at maintaining energy homeostasis. Interestingly, composition and abundance of pre-synaptic inputs onto arcuate AgRP and $\mathrm{POMC}$ neurons vary in the adult hypothalamus in response to changes in the metabolic state, a phenomenon that can be recapitulated by treatment with hormones, such as leptin or ghrelin. As described in other neuroendrocrine systems, glia might be determinant to shift the synaptic configuration of AgRP and POMC neurons. Here, we discuss the physiological outcome of the synaptic plasticity of the melanocortin system, and more particularly its contribution to the control of energy balance. The discovery of this attribute has changed how we view obesity and related disorders, and opens new perspectives for their management.

\section{Keywords: synaptic plasticity, melanocortin system, food intake, obesity, AgRP neurons, POMC neurons}

\section{Introduction}

Brain plasticity refers to the natural capacity of the brain to modify its structure and function through experience. This attribute relies on the property of neurons to adjust their responsiveness, molecular content, and connections as a result of activity. At the level of synapses, plasticity includes functional changes that strengthen or weaken existing synapses - by changing probability of neurotransmitter release and conductance and quantity of post-synaptic receptors - as well as structural changes that involve synapse formation and elimination (1). The hypothalamus, which ensures long-term stability of the inner milieu, is a brain area prone to synaptic plasticity. Neurotransmission in numerous neuronal circuits located in the hypothalamus varies in response to changes within the body and in the environment. This Review focuses on the structural forms of synaptic plasticity in the melanocortin system of the hypothalamus, one of the main neuronal circuits that control appetite and energy homeostasis. We also discuss recent findings suggesting that loss of plasticity in this 
circuit might compromise its function and confer risk for obesity and related disorders.

\section{Overview of the Melanocortin System}

Feeding behavior is controlled by several homeostatic brain circuits that promote food intake or suppress appetite according to metabolic needs, and by cognitive structures involved in hedonic hunger, eating habits, and emotional processing of the meal context (2). The melanocortin system is one of the most important neuronal pathways involved in the regulation of food intake and is probably the best characterized (3-7). This circuit includes (i) neurons expressing melanocortin receptors (MCR), namely central MC3R and MC4R subtypes, (ii) neurons that express MCR agonists, such as the melanocortin peptide called $\alpha$-melanocyte-stimulating hormone (MSH), which derives from the proopiomelanocortin (POMC) precursor protein, and (iii) neurons that express MCR antagonists, such as the high-affinity ligand agouti-related peptide (AgRP).

While MC3R and MC4R target neurons are widely distributed through the brain, they are highly enriched in specific brain areas controlling energy balance (8-10). The role of MC3R in energy homeostasis is not well understood yet, but MC3R neurons likely contribute to behavioral adaptation to fasting and nutrient partitioning $(11,12)$. Conversely, MCR4 is clearly involved in several aspects of energy balance, such as feeding behavior, adaptive thermogenesis, and glucose homeostasis (13-17). The anorectic and weight-lowering functions of MC4R have been evidenced using pharmacological and genetic tools in the late 1990s $(18,19)$. Moreover, mutations in the MC4R gene represent the most frequent genetic form of obesity and are associated with hyperphagia (20-22).

Interestingly, most of MC4R-expressing sites in the brain receive dual antagonistic innervation of stimulatory POMC and inhibitory AgRP fibers (23-25), suggesting that the melanocortin system is finely tuned to maintain energy homeostasis. POMCand AgRP-expressing neurons are contained in close proximity in the arcuate nucleus of the hypothalamus, but a small cluster of POMC neurons is also found in the solitary tract nucleus (nucleus tractus solitarii, NTS) in the brainstem (26-29). One special feature of the arcuate neurons is their position in a brain parenchyma flooded by blood-borne factors and cerebrospinal factors that are released by permeable microvessels of the median eminence and delivered by tanycytes lining the third ventricle (30-33). The ability of arcuate POMC and AgRP neurons to be regulated by circulating hormones, including leptin, insulin, ghrelin, estrogens, glucocorticoids, glucagon-like peptide 1, and peptide YY, and by nutrients makes the melanocortin system sensitive to changes in body's energy status (34-36). For instance, the adipose-derived signal leptin increases the activity of POMC neurons and inhibits that of AgRP neurons, which is consistent with the anorexigenic effect of this hormone $(29,37)$. Intrinsic particularities have been found in the melanocortin system based on the neurochemistry, anatomy, and sensitivity of its neuronal components. Arcuate but not NTS POMC neurons co-express the cocaine amphetamine-related peptide (CART), another anorexigenic molecule $(38,39)$. Moreover, arcuate POMC neurons are likely segregated into different projectional systems through the rostro-caudal axis of the hypothalamus, sending separated bundles of fibers to anterior brain structures (e.g., bed nucleus of the stria terminalis), lateral regions [e.g., paraventricular nucleus of the hypothalamus (PVN), lateral hypothalamus (LH), amygdala], or caudal regions (e.g., periaqueductal gray) $(23,25$, 40). Likewise, distinct subpopulations of arcuate AgRP neurons project to different brain regions (41). AgRP neurons co-express the orexigenic neuropeptide Y (NPY) $(42,43)$, and the neurotransmitter gamma-aminobutyric acid (GABA) that allows direct inhibition of POMC neurons (29). By contrast, arcuate POMC neurons exhibit diverse GABAergic, glutamatergic, and cholinergic neurotransmitter phenotypes (44-48), but the significance of this heterogeneity remains unclear (49). Nonetheless, divergence in the melanocortin system has been evidenced and the current model comprises dissociated sub-circuits that are dedicated to regulating specific parameters of the energy balance. For instance, MC4R-expressing single-minded homolog 1 (SIM1) neurons located in the PVN control appetite, while others in other parts of the brain control energy expenditure (50). Indeed, sympathetic preganglionic cholinergic MC4R-expressing neurons of the intermediolateral nucleus (IML) of the thoracic spinal cord regulate energy expenditure but not food intake (51).

Until recently, it was thought that AgRP neurons promote food intake via GABA- and NPY-mediated inhibition of local POMC neurons, and via AgRP-mediated competitive antagonism on distant MCR-expressing neurons $(3,52)$. The use of genetically encoded anatomical, optogenetic, and pharmacogenetic tools allowed for the identification of further modes of action of arcuate AgRP and POMC neurons in the control of food intake. In fact, the MCR signaling is not always mandatory for AgRP neurons to mediate their orexigenic effect. This has been exemplified in two different models. The first is based on selective ablation of AgRP neurons in adult mice. This procedure reduces the GABAergic tone from AgRP neurons within the parabrachial nucleus (PBN) of the hindbrain, a visceral and taste-sensing area, which leads to cessation of feeding and ultimately to death by starvation (53-55). In this specific hypothalamus-to-hindbrain circuit, AgRP innervation of the PBN maintains food intake in mice in a melanocortinindependent manner (54). The second model uses chemical- or light-mediated activation of melanocortin neurons in mice. These experiments show that artificial acute and selective activation of AgRP neurons is sufficient to rapidly induce voracious feeding (56, 57). Because this behavioral response is still found in Lethal yellow $\left(A^{y}\right)$ mutant mice, whose ectopic expression of the endogenous MCR antagonist Agouti blocks the melanocortin signaling, this indicates that MCR signaling is not necessary for AgRP neurons to initiate feeding (56). Conversely, photo-activation of POMC reduces food intake but the POMC-mediated anorexigenic effect is completely blocked by the $A^{y}$ mutation showing that POMC neurons require downstream melanocortin signaling to reduce food intake (56). Further studies have indicated that AgRP neurons control distinct phases of eating via specific molecular signaling pathways and neuronal circuits. NPY and GABA transmitters from AgRP neurons are involved in short-term regulation of food intake, whereas the AgRP peptide itself - as well as arcuate POMC neurons - controls food intake through an action on MC4R over 
a delayed and prolonged period (56, 58-60). A growing body of evidence suggests that AgRP and POMC neurons not only control homeostatic food intake but also motivate feeding behaviors, including desire to eat and food-seeking behavior (57), preference for flavors (61), visceral malaise anorexia (62), and reward-related behaviors (63). Furthermore, these neurons take into account the nutritional value and accessibility of food together with the internal physiological state to produce an anticipatory modulation of the feeding behavior (64). Finally, current model shows that AgRP neurons engage a constellation of parallel circuits and brain relays to control different aspects of feeding behavior, some of which have a redundant capability to drive feeding behavior (41).

\section{Evidences of Synaptic Plasticity in the Melanocortin System in Adult Brain}

Sensory experiences and changes in the inner milieu deeply modify the function of specialized neuronal circuits in the adult brain $(1,65,66)$. This capacity to adapt to ever-changing life conditions relies on coordinated molecular and cellular mechanisms, including changes in synaptic strength and in neuronal connectivity. The concept that the mature hypothalamus can undergo morphological plasticity according to variations of the physiological state and in response to hormonal cues is not a recent idea. In the 1980s, synaptic reorganization within the oxytocinergic system has been evidenced during lactation or in response to changes in water homeostasis $(67,68)$. In the same time, synaptic remodeling has been found in the hypothalamus in response to sex steroid hormones and during the estrous cycle $(69,70)$. This hormone-dependent synaptic plasticity affects gonadotropin releasing hormone $(\mathrm{GnRH})$ neurons involved in the neuroendocrine control of reproduction (71). During the two last decades, Tamas Horvath and colleagues have clearly established that the melanocortin system is another hypothalamic system whose connectivity is affected by variation in circulating hormones (72). Pioneer studies were based on depletion-repletion paradigms in living animals to control hormone levels combined with in-depth inspection of synaptic organization on arcuate POMC and NPY neurons (73-75). In the first report, the situation in mutant $o b / o b$ mice lacking leptin was compared to that of wild-type and leptinsupplemented ob/ob mice (73). Electron microscopic stereology on fixed brain sections combined to ex vivo electrophysiological recordings of living brain slices revealed that leptin induces a shift in the composition of afferent inputs on POMC neurons in adult brain, by increasing excitatory synapses apposed on these cells within only $6 \mathrm{~h}$ following intraperitoneal injection. Opposite effects were found on NPY/AgRP neurons. Interestingly, leptininduced synaptic changes are consistent with the anorectic effect of leptin suggesting that a causal relation might exist. Similar strategies were used to evidence remodeling properties of estradiol and corticosterone, whose effects on the connectivity of the adult melanocortin system are still consistent with their physiological actions $(74,75)$. Further studies have revealed that injection of ghrelin in wild-type mice also causes synaptic remodeling on POMC and NPY/AgRP neurons $(73,76)$. All these observations clearly indicate the ability of the adult melanocortin to rewire in response to metabolic cues.

\section{Connectivity of the Melanocortin System is Nutritionally Regulated}

Plasticity of the melanocortin system in adult brain has been initially evidenced in response to hormone replacement in depleted backgrounds found in mutant $o b / o b$, ovariectomized, or adrenalectomized mice (73-75). This discovery markedly changed our understanding of how hormones regulate the melanocortin system. A second breakthrough was achieved in the early 2010 s when it was shown that synaptic rearrangement on POMC and $\mathrm{NPY} /$ AgRP neurons naturally occurs in naïve animals in response to changes in the nutritional state.

During positive energy balance, high level of circulating leptin stimulates arcuate leptin-sensitive POMC neurons, which might activate anorexigenic MC4R-signaling in downstream neurons via $\alpha$-MSH release $(29,77,78)$. In parallel, leptin blunts the tonic AgRP activity by reducing excitatory inputs on AgRP neurons through an opioid receptor-dependent pathway (78). It is likely the release of $\beta$-endorphin from leptin-stimulated POMC neurons that downregulates the glutamatergic activity on AgRP neurons (78).

Food deprivation induces synaptic remodeling in both AgRP and POMC neurons (77-79). Orexigenic ghrelin, which is elevated after fasting (80), promotes excitatory glutamate release onto AgRP neurons (78). $\mathrm{Ca}^{2+}$ and AMPK intracellular signaling in presynaptic glutamatergic neurons mediates this effect (78). N-methyl$\mathrm{D}$-aspartate (NMDA) receptors and spinogenesis in AgRP neurons are also required to increase AgRP activity during fasting (79). In addition, the inhibitory tone on POMC neurons increases when blood leptin level falls during fasting $(77,78)$. Fasting-induced inhibition of POMC neurons might result from ghrelin-activated GABAergic AgRP neurons that innervate POMC neurons $(29,58$, $77,81)$ but is also caused by apposition of new inhibitory terminals on POMC neurons, which are non-AgRP GABAergic neurons (77).

Finally, the current model for food deprivation-induced neuronal rewiring implies two opposite signals acting on several cell targets (Figure 1). Ghrelin rewires the melanocortin system during negative energy balance and basal synaptic organization is recovered by the rise of leptin when energy balance is restored. In this model, leptin is viewed as a resetting signal. On the other hand, overfeeding for few days, which is associated with high leptin level, is another nutritional situation that initiates synaptic remodeling in the melanocortin system (82). Precisely, shortterm high-fat diet for 3 days increases excitatory inputs on POMC neurons. This observation indicates that synaptic plasticity of AgRP and POMC neurons is not a specific response to fasting and suggests that synaptic remodeling is activated after positive or negative deviation from the metabolic set point. Underlying biological mediators, molecular pathways as well as origin of dynamic synapses probably differ for each situation.

\section{Astrocytes Regulate the Connectivity of Melanocortin Neurons}

Initially viewed as the "brain glue," i.e., an inert scaffold for neural tissues, and then as non-excitable supporting and nourishing cells for neurons, astrocytes are now considered as key players in neurotransmission (83). Recently, it has been proposed that 


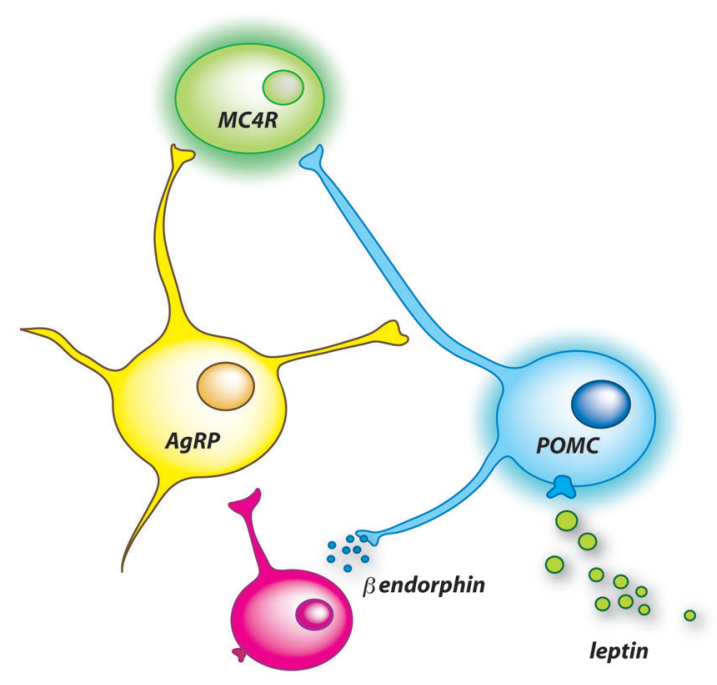

Fed state

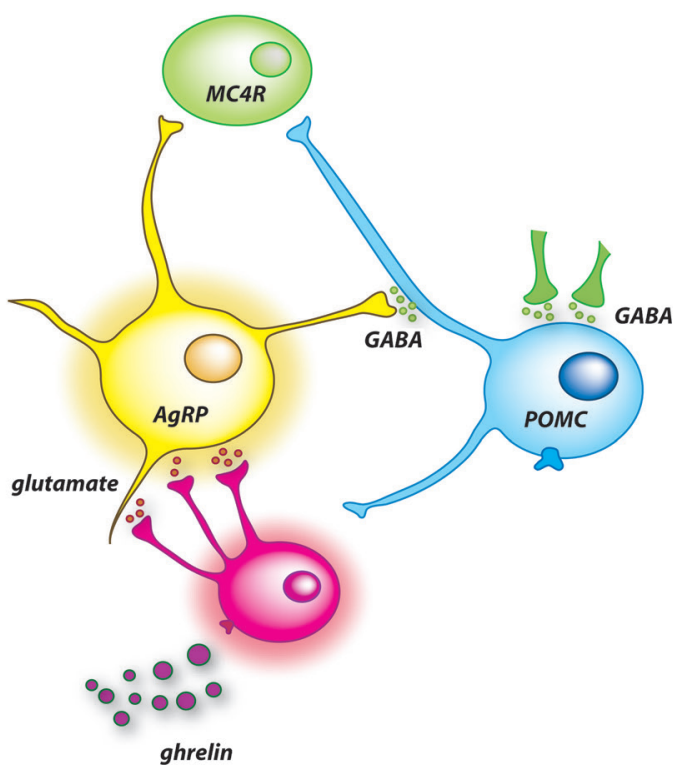

Fasted state

FIGURE 1 | Model illustrating the synaptic remodeling on arcuate AgRP and POMC neurons after food deprivation. In the fed state (left panel), high level of circulating leptin stimulates POMC neurons, which probably activate MC4R downstream neurons to limit further food intake. Leptin also causes the release of $\beta$-endorphin from POMC neurons. This endogenous opioid blunts the activity of AgRP neurons by reducing the excitatory glutamatergic tone applied on them. Food deprivation raises the level of circulating ghrelin (right panel). This orexigenic hormone promotes apposition of new excitatory synapses on AgRP neurons that increases the activity of these cells. The concomitant drop of blood leptin allows the insertion of inhibitory terminals on POMC cells. These additional inhibitory synapses originate mainly from non-AgRP GABAergic neurons.

these glial cells contribute to the brain control of energy balance (84-86). In fact, astrocytes are at the interface between blood vessels and neurons (87). Expression of sensors for metabolic signals, including those for glucose, fatty acids, insulin, leptin, insulin-like growth factor-1 (IGF1), and glucocorticoids, give to astrocytes the ability to integrate changes in the microenvironment that might be communicated to neurons (88-96). Obviously, hypothalamic and hindbrain astrocytes are glucosensitive cells involved in several physiological functions, including glucose homeostasis and gastric motility (97-100). Moreover, leptin regulates the expression of glutamate and glucose transporters in hypothalamic astrocytes (101). Alteration of leptin signaling in astrocytes causes aberrant feeding responses to fasting and to leptin or ghrelin injections (96). Feeding response to high-fat diet is also impaired by disruption of the nuclear factor kappa-light-chain-enhancer of activated B cells (NF- $\mathrm{KB}$ ) pathway in astrocytes (102). All these data support the idea that astrocytes contribute to the control of food intake. However, the mode of action of astrocytes for modulating activity of feeding circuits is not totally elucidated. Indeed, they act on neurons through a wide variety of mechanisms. These glial cells modulate neuronal excitability and synaptic transmission via the clearance of synaptic transmitters and the delivery of signaling compounds, called gliotransmitters, such as protons, lactate, and adenosine $(103,104)$. For instance, blood osmolality is nutritionally regulated through a ghrelin-dependent astrocytic ATP release on vasopressin neurons (105). Furthermore, it has been shown that astrocytes control food intake by inhibiting AgRP neurons via adenosine A1 receptors (106). Astrocytes also produce bioactive molecules, such as apolipoprotein E (ApoE), the most abundant lipid transporter in the brain, which acts in the hypothalamus as a satiety factor by reducing food intake after central administration (107). Modification of astrocyte coverage at the synapses is another mean to efficiently and rapidly modulate the synaptic strength onto neurons (108-110). Time-lapse imaging shows that perisynaptic astrocytic processes that embrace synapses are highly reactive and motile structures, to an even higher degree than dendritic spines (111). Interestingly, leptin alters the expression of structural proteins, such as glial fibrillary acidic protein (GFAP), actin, and vimentin, in astrocytes, which is accompanied by changes in astrocytes morphology (112). Furthermore, the morphology of astrocytes surrounding arcuate POMC and AgRP soma varies in the adult brain according to nutritional history, metabolic state, and leptin signaling $(96,101,113)$. These morphological changes significantly influence the synaptic inputs received by melanocortin neurons, which might affect overall activity of the system and ultimately the feeding behavior $(96,101,113)$.

\section{Physiological Relevance of Synaptic Plasticity in the Melanocortin System}

The ability of the brain to change physically and functionally following experience is a way to adapt to changing environment. 
Thus, rearrangement of pre-synaptic contacts onto AgRP and POMC neurons in response to metabolic cues would serve to adjust the reactiveness of the melanocortin circuit and to finely control feeding behavior according to energy availability. This attribute would avoid stereotyped responses and maladaptive behaviors. For instance, in fasted animals synaptic remodeling in AgRP and POMC neurons might contribute to increase sensitivity for food cues and/or to increase threshold for satiety signals in order to increase meal size following food deprivation. However, such relation has not been established yet. Nevertheless, it is very likely that the plasticity of the melanocortin system is involved in the regulation of food intake and energy homeostasis. First, because the synaptic rearrangement on AgRP and/or POMC neurons naturally occurs in adult animals in response to positive or negative deviation from a metabolic steady state, i.e., situations that require central regulation of energy metabolism and behavior $(78,79,82)$. Second, because the synaptic rearrangement on AgRP and/or POMC neurons caused by metabolic imbalance is consistent with the activation of a counter-regulatory response mediated by changes in AgRP and POMC neuronal activity (78, $79,82)$. This observation is in line with seminal reports showing that hormones affect AgRP and POMC synaptology in a manner compatible with their effects on food intake and body weight regulation $(73-75,78)$. Third, because removal of polysialic acid (PSA), a major synaptic plasticity-promoting factor, from the hypothalamus not only inhibits POMC neurons rewiring during overfeeding but also blunts the following normalization of energy intake (82). While the permissive factor PSA was not selectively ablated in POMC cells in this study - but removed in the whole hypothalamus - these results suggest that POMC rewiring induced by dietary fat consumption contributes to the homeostatic control of food intake. Further studies based on cell-specific manipulation of synaptic plasticity in adult animals are definitively needed to characterize physiological consequences of plasticity-related mechanisms caused by changes in the nutritional state.

\section{Conclusion and Perspectives}

Synaptic plasticity of the melanocortin system is currently considered as an adaptive process activated by huge variations in circulating hormones that can be seen during extreme metabolic circumstances, such as 3-day overfeeding and 24-h fasting in rodents. Other plasticity-related processes occur in response to these metabolic challenges. Overfeeding increases cell proliferation in the mouse brain within few days (114). Blocking the early proliferative burst impairs the normalization of energy intake on the short term. In addition, percentage of newly generated cells

\section{References}

1. Holtmaat A, Svoboda K. Experience-dependent structural synaptic plasticity in the mammalian brain. Nat Rev Neurosci (2009) 10:647-58. doi:10.1038/ nrn2699

2. Berthoud HR. Metabolic and hedonic drives in the neural control of appetite: who is the boss? Curr Opin Neurobiol (2011) 21:888-96. doi:10.1016/j. conb.2011.09.004

3. Cone RD. Anatomy and regulation of the central melanocortin system. Nat Neurosci (2005) 8:571-8. doi:10.1038/nn1455 adopting a POMC-phenotype in the arcuate nucleus is increased on the long term. This suggests that cell renewal is accelerated during metabolic imbalance, and that maturation of newborn cells is nutritionally regulated to maintain energy homeostasis. On the other hand, fasting induces remodeling of the tanycytic barrier and change in permeability of capillaries in the median eminence and the arcuate nucleus of the hypothalamus, a process that modifies blood-brain exchanges and diffusion of bloodborne molecules into the arcuate parenchyma (31). Structural remodeling in brain feeding centers likely strengthens functional plasticity based on pure pharmacological mechanisms within circuits. Indeed, high-fat feeding induces transient suppression of orexigenic neuropeptides and subsequent induction of anorexigenic neuropeptides (115). Secretion of neuropeptides from POMC neurons can be changed selectively, which further increases the plasticity of the melanocortin system. Activation of cannabinoid receptor $1\left(\mathrm{CB}_{1} \mathrm{R}\right)$ induces $\beta$-endorphin release, but not $\alpha$-MSH, in a subset of POMC neurons, and thereby shifts the function of these appetite-suppressing neurons and increases feeding behavior (116). Interestingly, neurotransmission in the dopaminergic system of the ventral tegmental area is also regulated according to the metabolic state and this regulation involves endocannabinoids too (117). This mechanism might serve to modulate the anticipatory activity and preference for food-related cues. Thus, plasticity of the melanocortin system might be an element of a protecting arsenal based on disseminated structural and functional changes throughout the brain that are engaged during metabolic imbalance.

Metabolic magnetic resonance imaging has shown that the human hypothalamus is competent for plasticity (118). Therefore, it would not be surprising to find in the human brain plasticity-related events similar to those that have been detected in the melanocortin system of laboratory animals. As a corollary, deficiency in the ability to rewire feeding circuits ondemand would confer a risk for maladaptive feeding behaviors, obesity, and related disorders. This hypothesis has been recently strengthened by a meta-analysis of genome-wide association studies for body mass index in human that has brought to the front of the scene the role of the central nervous system in obesity susceptibility, implicating genes related to synaptic function and plasticity (119).

\section{Acknowledgments}

This work was supported by the "Centre National de la Recherche Scientifique" and by a grant from the "Agence Nationale de la Recherche" (ANR-13-JSV1-0003-01 to AB).

4. Ellacott KL, Cone RD. The role of the central melanocortin system in the regulation of food intake and energy homeostasis: lessons from mouse models. Philos Trans R Soc Lond B Biol Sci (2006) 361:1265-74. doi:10.1098/ rstb.2006.1861

5. Garfield AS, Lam DD, Marston OJ, Przydzial MJ, Heisler LK. Role of central melanocortin pathways in energy homeostasis. Trends Endocrinol Metab (2009) 20:203-15. doi:10.1016/j.tem.2009.02.002

6. Xu Y, Elmquist JK, Fukuda M. Central nervous control of energy and glucose balance: focus on the central melanocortin system. Ann N Y Acad Sci (2011) 1243:1-14. doi:10.1111/j.1749-6632.2011.06248.x 
7. Mountjoy KG. Pro-opiomelanocortin (POMC) neurones, POMC-derived peptides, melanocortin receptors and obesity: how understanding of this system has changed over the last decade. JNeuroendocrinol (2015) 27:406-18. doi:10.1111/jne.12285

8. Mountjoy KG, Mortrud MT, Low MJ, Simerly RB, Cone RD. Localization of the melanocortin-4 receptor (MC4-R) in neuroendocrine and autonomic control circuits in the brain. Mol Endocrinol (1994) 8:1298-308. doi:10.1210/ me.8.10.1298

9. Kishi T, Aschkenasi CJ, Lee CE, Mountjoy KG, Saper CB, Elmquist JK. Expression of melanocortin 4 receptor mRNA in the central nervous system of the rat. J Comp Neurol (2003) 457:213-35. doi:10.1002/cne.10454

10. Liu H, Kishi T, Roseberry AG, Cai X, Lee CE, Montez JM, et al. Transgenic mice expressing green fluorescent protein under the control of the melanocortin-4 receptor promoter. J Neurosci (2003) 23:7143-54.

11. Begriche K, Marston OJ, Rossi J, Burke LK, Mcdonald P, Heisler LK, et al. Melanocortin-3 receptors are involved in adaptation to restricted feeding. Genes Brain Behav (2012) 11:291-302. doi:10.1111/j.1601-183X.2012.00766.x

12. Renquist BJ, Murphy JG, Larson EA, Olsen D, Klein RF, Ellacott KL, et al. Melanocortin-3 receptor regulates the normal fasting response. Proc Natl Acad Sci U S A (2012) 109:E1489-98. doi:10.1073/pnas.1201994109

13. Voss-Andreae A, Murphy JG, Ellacott KL, Stuart RC, Nillni EA, Cone RD, et al. Role of the central melanocortin circuitry in adaptive thermogenesis of brown adipose tissue. Endocrinology (2007) 148:1550-60. doi:10.1210/ en.2006-1389

14. Sohn JW, Harris LE, Berglund ED, Liu T, Vong L, Lowell BB, et al. Melanocortin 4 receptors reciprocally regulate sympathetic and parasympathetic preganglionic neurons. Cell (2013) 152:612-9. doi:10.1016/j.cell.2012.12.022

15. Shah BP, Vong L, Olson DP, Koda S, Krashes MJ, Ye C, et al. MC4R-expressing glutamatergic neurons in the paraventricular hypothalamus regulate feeding and are synaptically connected to the parabrachial nucleus. Proc Natl Acad Sci U S A (2014) 111:13193-8. doi:10.1073/pnas.1407843111

16. Garfield AS, Li C, Madara JC, Shah BP, Webber E, Steger JS, et al. A neural basis for melanocortin-4 receptor-regulated appetite. Nat Neurosci (2015) 18:863-71. doi:10.1038/nn.4011

17. Morgan DA, Mcdaniel LN, Yin T, Khan M, Jiang J, Acevedo MR, et al. Regulation of glucose tolerance and sympathetic activity by MC4R signaling in the lateral hypothalamus. Diabetes (2015) 64:1976-87. doi:10.2337/ db14-1257

18. Fan W, Boston BA, Kesterson RA, Hruby VJ, Cone RD. Role of melanocortinergic neurons in feeding and the agouti obesity syndrome. Nature (1997) 385:165-8. doi:10.1038/385165a0

19. Huszar D, Lynch CA, Fairchild-Huntress V, Dunmore JH, Fang Q, Berkemeier LR, et al. Targeted disruption of the melanocortin- 4 receptor results in obesity in mice. Cell (1997) 88:131-41. doi:10.1016/S0092-8674(00)81865-6

20. Hinney A, Schmidt A, Nottebom K, Heibult O, Becker I, Ziegler A, et al. Several mutations in the melanocortin-4 receptor gene including a nonsense and a frameshift mutation associated with dominantly inherited obesity in humans. J Clin Endocrinol Metab (1999) 84:1483-6. doi:10.1210/ jcem.84.4.5728

21. Farooqi IS, Yeo GS, Keogh JM, Aminian S, Jebb SA, Butler G, et al. Dominant and recessive inheritance of morbid obesity associated with melanocortin 4 receptor deficiency. J Clin Invest (2000) 106:271-9. doi:10.1172/JCI9397

22. Vaisse C, Clement K, Durand E, Hercberg S, Guy-Grand B, Froguel P. Melanocortin-4 receptor mutations are a frequent and heterogeneous cause of morbid obesity. J Clin Invest (2000) 106:253-62. doi:10.1172/JCI9238

23. Bagnol D, Lu XY, Kaelin CB, Day HE, Ollmann M, Gantz I, et al. Anatomy of an endogenous antagonist: relationship between Agouti-related protein and proopiomelanocortin in brain. J Neurosci (1999) 19:RC26.

24. Haskell-Luevano C, Chen P, Li C, Chang K, Smith MS, Cameron JL, et al. Characterization of the neuroanatomical distribution of agouti-related protein immunoreactivity in the rhesus monkey and the rat. Endocrinology (1999) 140:1408-15. doi:10.1210/en.140.3.1408

25. Wang D, He X, Zhao Z, Feng Q, Lin R, Sun Y, et al. Whole-brain mapping of the direct inputs and axonal projections of POMC and AgRP neurons. Front Neuroanat (2015) 9:40. doi:10.3389/fnana.2015.00040

26. Joseph SA, Pilcher WH, Bennett-Clarke C. Immunocytochemical localization of ACTH perikarya in nucleus tractus solitarius: evidence for a second opiocortin neuronal system. Neurosci Lett (1983) 38:221-5. doi:10.1016/0304-3940(83)90372-5

27. Schwartzberg DG, Nakane PK. ACTH-related peptide containing neurons within the medulla oblongata of the rat. Brain Res (1983) 276:351-6. doi:10.1016/0006-8993(83)90746-1

28. Palkovits M, Mezey E, Eskay RL. Pro-opiomelanocortin-derived peptides (ACTH/beta-endorphin/alpha-MSH) in brainstem baroreceptor areas of the rat. Brain Res (1987) 436:323-38. doi:10.1016/0006-8993(87)91676-3

29. Cowley MA, Smart JL, Rubinstein M, Cerdan MG, Diano S, Horvath TL, et al. Leptin activates anorexigenic POMC neurons through a neural network in the arcuate nucleus. Nature (2001) 411:480-4. doi:10.1038/35078085

30. Ciofi P, Garret M, Lapirot O, Lafon P, Loyens A, Prevot V, et al. Brainendocrine interactions: a microvascular route in the mediobasal hypothalamus. Endocrinology (2009) 150:5509-19. doi:10.1210/en.2009-0584

31. Langlet F, Levin BE, Luquet S, Mazzone M, Messina A, Dunn-Meynell AA, et al. Tanycytic VEGF-A boosts blood-hypothalamus barrier plasticity and access of metabolic signals to the arcuate nucleus in response to fasting. Cell Metab (2013) 17:607-17. doi:10.1016/j.cmet.2013.03.004

32. Schaeffer M, Langlet F, Lafont C, Molino F, Hodson DJ, Roux T, et al. Rapid sensing of circulating ghrelin by hypothalamic appetite-modifying neurons. Proc Natl Acad Sci U S A (2013) 110:1512-7. doi:10.1073/pnas.1212137110

33. Balland E, Dam J, Langlet F, Caron E, Steculorum S, Messina A, et al. Hypothalamic tanycytes are an ERK-gated conduit for leptin into the brain. Cell Metab (2014) 19:293-301. doi:10.1016/j.cmet.2013.12.015

34. Blouet C, Schwartz GJ. Hypothalamic nutrient sensing in the control of energy homeostasis. Behav Brain Res (2010) 209:1-12. doi:10.1016/j.bbr.2009.12.024

35. Mountjoy KG. Functions for pro-opiomelanocortin-derived peptides in obesity and diabetes. Biochem J (2010) 428:305-24. doi:10.1042/BJ20091957

36. Sohn JW, Elmquist JK, Williams KW. Neuronal circuits that regulate feeding behavior and metabolism. Trends Neurosci (2013) 36:504-12. doi:10.1016/j. tins.2013.05.003

37. Baver SB, Hope K, Guyot S, Bjorbaek C, Kaczorowski C, O’Connell KM. Leptin modulates the intrinsic excitability of AgRP/NPY neurons in the arcuate nucleus of the hypothalamus. J Neurosci (2014) 34:5486-96. doi:10.1523/ JNEUROSCI.4861-12.2014

38. Elias CF, Lee C, Kelly J, Aschkenasi C, Ahima RS, Couceyro PR, et al. Leptin activates hypothalamic CART neurons projecting to the spinal cord. Neuron (1998) 21:1375-85. doi:10.1016/S0896-6273(00)80656-X

39. Ellacott KL, Halatchev IG, Cone RD. Characterization of leptin-responsive neurons in the caudal brainstem. Endocrinology (2006) 147:3190-5. doi:10.1210/en.2005-0877

40. KhachaturianH,LewisME,HaberSN,AkilH, WatsonSJ.Proopiomelanocortin peptide immunocytochemistry in rhesus monkey brain. Brain Res Bull (1984) 13:785-800. doi:10.1016/0361-9230(84)90237-5

41. Betley JN, Cao ZF, Ritola KD, Sternson SM. Parallel, redundant circuit organization for homeostatic control of feeding behavior. Cell (2013) 155:1337-50. doi:10.1016/j.cell.2013.11.002

42. Broberger C, Johansen J, Johansson C, Schalling M, Hokfelt T. The neuropeptide Y/agouti gene-related protein (AGRP) brain circuitry in normal, anorectic, and monosodium glutamate-treated mice. Proc Natl Acad Sci U S A (1998) 95:15043-8. doi:10.1073/pnas.95.25.15043

43. Hahn TM, Breininger JF, Baskin DG, Schwartz MW. Coexpression of Agrp and NPY in fasting-activated hypothalamic neurons. Nat Neurosci (1998) 1:271-2. doi:10.1038/1082

44. Hentges ST, Nishiyama M, Overstreet LS, Stenzel-Poore M, Williams JT, Low MJ. GABA release from proopiomelanocortin neurons. J Neurosci (2004) 24:1578-83. doi:10.1523/JNEUROSCI.3952-03.2004

45. Meister B, Gomuc B, Suarez E, Ishii Y, Durr K, Gillberg L. Hypothalamic proopiomelanocortin (POMC) neurons have a cholinergic phenotype. Eur J Neurosci (2006) 24:2731-40. doi:10.1111/j.1460-9568.2006.05157.x

46. Hentges ST, Otero-Corchon V, Pennock RL, King CM, Low MJ. Proopiomelanocortin expression in both GABA and glutamate neurons. J Neurosci (2009) 29:13684-90. doi:10.1523/JNEUROSCI.3770-09.2009

47. Jarvie BC, Hentges ST. Expression of GABAergic and glutamatergic phenotypic markers in hypothalamic proopiomelanocortin neurons. J Comp Neurol (2012) 520:3863-76. doi:10.1002/cne.23127

48. Wittmann G, Hrabovszky E, Lechan RM. Distinct glutamatergic and GABAergic subsets of hypothalamic pro-opiomelanocortin neurons 
revealed by in situ hybridization in male rats and mice. J Comp Neurol (2013) 521:3287-302. doi:10.1002/cne.23350

49. Mercer AJ, Hentges ST, Meshul CK, Low MJ. Unraveling the central proopiomelanocortin neural circuits. Front Neurosci (2013) 7:19. doi:10.3389/ fnins.2013.00019

50. Balthasar N, Dalgaard LT, Lee CE, Yu J, Funahashi H, Williams T, et al. Divergence of melanocortin pathways in the control of food intake and energy expenditure. Cell (2005) 123:493-505. doi:10.1016/j.cell.2005.08.035

51. Rossi J, Balthasar N, Olson D, Scott M, Berglund E, Lee CE, et al. Melanocortin-4 receptors expressed by cholinergic neurons regulate energy balance and glucose homeostasis. Cell Metab (2011) 13:195-204. doi:10.1016/j.cmet.2011.01.010

52. Morton GJ, Cummings DE, Baskin DG, Barsh GS, Schwartz MW. Central nervous system control of food intake and body weight. Nature (2006) 443:289-95. doi:10.1038/nature05026

53. Luquet S, Perez FA, Hnasko TS, Palmiter RD. NPY/AgRP neurons are essential for feeding in adult mice but can be ablated in neonates. Science (2005) 310:683-5. doi:10.1126/science.1115524

54. Wu Q, Howell MP, Cowley MA, Palmiter RD. Starvation after AgRP neuron ablation is independent of melanocortin signaling. Proc Natl Acad Sci U S A (2008) 105:2687-92. doi:10.1073/pnas.0712062105

55. Wu Q, Boyle MP, Palmiter RD. Loss of GABAergic signaling by AgRP neurons to the parabrachial nucleus leads to starvation. Cell (2009) 137:1225-34. doi:10.1016/j.cell.2009.04.022

56. Aponte Y, Atasoy D, Sternson SM. AGRP neurons are sufficient to orchestrate feeding behavior rapidly and without training. Nat Neurosci (2011) 14:351-5. doi:10.1038/nn.2739

57. Krashes MJ, Koda S, Ye C, Rogan SC, Adams AC, Cusher DS, et al. Rapid, reversible activation of AgRP neurons drives feeding behavior in mice. J Clin Invest (2011) 121:1424-8. doi:10.1172/JCI46229

58. Atasoy D, Betley JN, Su HH, Sternson SM. Deconstruction of a neural circuit for hunger. Nature (2012) 488:172-7. doi:10.1038/nature11270

59. Krashes MJ, Shah BP, Koda S, Lowell BB. Rapid versus delayed stimulation of feeding by the endogenously released AgRP neuron mediators GABA, NPY, and AgRP. Cell Metab (2013) 18:588-95. doi:10.1016/j.cmet.2013.09.009

60. Zhan C, Zhou J, Feng Q, Zhang JE, Lin S, Bao J, et al. Acute and long-term suppression of feeding behavior by POMC neurons in the brainstem and hypothalamus, respectively. J Neurosci (2013) 33:3624-32. doi:10.1523/ JNEUROSCI.2742-12.2013

61. Betley JN, Xu S, Cao ZF, Gong R, Magnus CJ, Yu Y, et al. Neurons for hunger and thirst transmit a negative-valence teaching signal. Nature (2015) 521:180-5. doi:10.1038/nature14416

62. Carter ME, Soden ME, Zweifel LS, Palmiter RD. Genetic identification of a neural circuit that suppresses appetite. Nature (2013) 503:111-4. doi:10.1038/ nature 12596

63. Dietrich MO, Bober J, Ferreira JG, Tellez LA, Mineur YS, Souza DO, et al. AgRP neurons regulate development of dopamine neuronal plasticity and nonfood-associated behaviors. Nat Neurosci (2012) 15:1108-10. doi:10.1038/ nn. 3147

64. Chen Y, Lin YC, Kuo TW, Knight ZA. Sensory detection of food rapidly modulates arcuate feeding circuits. Cell (2015) 160:829-41. doi:10.1016/j. cell.2015.01.033

65. Barth C, Villringer A, Sacher J. Sex hormones affect neurotransmitters and shape the adult female brain during hormonal transition periods. Front Neurosci (2015) 9:37. doi:10.3389/fnins.2015.00037

66. Ebling FJ. Hypothalamic control of seasonal changes in food intake and body weight. Front Neuroendocrinol (2015) 37:97-107. doi:10.1016/j. yfrne.2014.10.003

67. Chapman DB, Theodosis DT, Montagnese C, Poulain DA, Morris JF. Osmotic stimulation causes structural plasticity of neurone-glia relationships of the oxytocin but not vasopressin secreting neurones in the hypothalamic supraoptic nucleus. Neuroscience (1986) 17:679-86. doi:10.1016/0306-4522(86)90039-4

68. Theodosis DT, Montagnese C, Rodriguez F, Vincent JD, Poulain DA. Oxytocin induces morphological plasticity in the adult hypothalamo-neurohypophysial system. Nature (1986) 322:738-40. doi:10.1038/322738a0

69. Garcia-Segura LM, Baetens D, Naftolin F. Synaptic remodelling in arcuate nucleus after injection of estradiol valerate in adult female rats. Brain Res (1986) 366:131-6. doi:10.1016/0006-8993(86)91287-4
70. Olmos G, Naftolin F, Perez J, Tranque PA, Garcia-Segura LM. Synaptic remodeling in the rat arcuate nucleus during the estrous cycle. Neuroscience (1989) 32:663-7. doi:10.1016/0306-4522(89)90288-1

71. Naftolin F, Garcia-Segura LM, Horvath TL, Zsarnovszky A, Demir N, Fadiel A, et al. Estrogen-induced hypothalamic synaptic plasticity and pituitary sensitization in the control of the estrogen-induced gonadotrophin surge. Reprod Sci (2007) 14:101-16. doi:10.1177/1933719107301059

72. Dietrich MO, Horvath TL. Hypothalamic control of energy balance: insights into the role of synaptic plasticity. Trends Neurosci (2013) 36:65-73. doi:10.1016/j.tins.2012.12.005

73. Pinto S, Roseberry AG, Liu H, Diano S, Shanabrough M, Cai X, et al. Rapid rewiring of arcuate nucleus feeding circuits by leptin. Science (2004) 304:110-5. doi:10.1126/science.1089459

74. Gao Q, Mezei G, Nie Y, Rao Y, Choi CS, Bechmann I, et al. Anorectic estrogen mimics leptin's effect on the rewiring of melanocortin cells and Stat3 signaling in obese animals. Nat Med (2007) 13:89-94. doi:10.1038/nm 1525

75. Gyengesi E, Liu ZW, D’Agostino G, Gan G, Horvath TL, Gao XB, et al. Corticosterone regulates synaptic input organization of POMC and NPY/AgRP neurons in adult mice. Endocrinology (2010) 151:5395-402. doi:10.1210/en.2010-0681

76. Andrews ZB, Liu ZW, Walllingford N, Erion DM, Borok E, Friedman JM, et al. UCP2 mediates ghrelin's action on NPY/AgRP neurons by lowering free radicals. Nature (2008) 454:846-51. doi:10.1038/nature07181

77. Vong L, Ye C, Yang Z, Choi B, Chua S Jr, Lowell BB. Leptin action on GABAergic neurons prevents obesity and reduces inhibitory tone to POMC neurons. Neuron (2011) 71:142-54. doi:10.1016/j.neuron.2011.05.028

78. Yang Y, Atasoy D, Su HH, Sternson SM. Hunger states switch a flip-flop memory circuit via a synaptic AMPK-dependent positive feedback loop. Cell (2011) 146:992-1003. doi:10.1016/j.cell.2011.07.039

79. Liu T, Kong D, Shah BP, Ye C, Koda S, Saunders A, et al. Fasting activation of AgRP neurons requires NMDA receptors and involves spinogenesis and increased excitatory tone. Neuron (2012) 73:511-22. doi:10.1016/j. neuron.2011.11.027

80. Tschop M, Smiley DL, Heiman ML. Ghrelin induces adiposity in rodents. Nature (2000) 407:908-13. doi:10.1038/35038090

81. Tong Q, Ye CP, Jones JE, Elmquist JK, Lowell BB. Synaptic release of GABA by AgRP neurons is required for normal regulation of energy balance. Nat Neurosci (2008) 11:998-1000. doi:10.1038/nn.2167

82. Benani A, Hryhorczuk C, Gouaze A, Fioramonti X, Brenachot X, Guissard C, et al. Food intake adaptation to dietary fat involves PSA-dependent rewiring of the arcuate melanocortin system in mice. J Neurosci (2012) 32:11970-9. doi:10.1523/JNEUROSCI.0624-12.2012

83. Volterra A, Meldolesi J. Astrocytes, from brain glue to communication elements: the revolution continues. Nat Rev Neurosci (2005) 6:626-40. doi:10.1038/nrn1722

84. Garcia-Caceres C, Fuente-Martin E, Argente J, Chowen JA. Emerging role of glial cells in the control of body weight. Mol Metab (2012) 1:37-46. doi:10.1016/j.molmet.2012.07.001

85. Buckman LB, Ellacott KL. The contribution of hypothalamic macroglia to the regulation of energy homeostasis. Front Syst Neurosci (2014) 8:212. doi:10.3389/fnsys.2014.00212

86. Argente-Arizon P, Freire-Regatillo A, Argente J, Chowen JA. Role of non-neuronal cells in body weight and appetite control. Front Endocrinol (2015) 6:42. doi:10.3389/fendo.2015.00042

87. Teschemacher AG, Gourine AV, Kasparov S. A role for astrocytes in sensing the brain microenvironment and neuro-metabolic integration. Neurochem Res (2015). doi:10.1007/s11064-015-1562-9

88. Kum W, Cockram CS, Zhu SQ, Teoh R, Vallance-Owen J, Young JD. Insulin binding and effects on pyrimidine nucleoside uptake and incorporation in cultured mouse astrocytes. J Neurochem (1987) 49:1293-300. doi:10.111 1/j.1471-4159.1987.tb10023.x

89. Vielkind U, Walencewicz A, Levine JM, Bohn MC. Type II glucocorticoid receptors are expressed in oligodendrocytes and astrocytes. J Neurosci Res (1990) 27:360-73. doi:10.1002/jnr.490270315

90. Vannucci SJ, Maher F, Simpson IA. Glucose transporter proteins in brain: delivery of glucose to neurons and glia. Glia (1997) 21:2-21. doi:10.1002/ (SICI) 1098-1136(199709)21:1<2::AID-GLIA2>3.0.CO;2-C 
91. Cardona-Gomez GP, Chowen JA, Garcia-Segura LM. Estradiol and progesterone regulate the expression of insulin-like growth factor-I receptor and insulin-like growth factor binding protein-2 in the hypothalamus of adult female rats. J Neurobiol (2000) 43:269-81. doi:10.1002/ (SICI) 1097-4695(20000605)43:3<269::AID-NEU5>3.0.CO;2-D

92. Cardona-Gomez GP, Doncarlos L, Garcia-Segura LM. Insulin-like growth factor I receptors and estrogen receptors colocalize in female rat brain. Neuroscience (2000) 99:751-60. doi:10.1016/S0306-4522(00)00228-1

93. Cheunsuang O, Morris R. Astrocytes in the arcuate nucleus and median eminence that take up a fluorescent dye from the circulation express leptin receptors and neuropeptide Y Y1 receptors. Glia (2005) 52:228-33. doi:10.1002/glia.20239

94. Hsuchou H, He Y, Kastin AJ, Tu H, Markadakis EN, Rogers RC, et al. Obesity induces functional astrocytic leptin receptors in hypothalamus. Brain (2009) 132:889-902. doi:10.1093/brain/awp029

95. Hsuchou H, Pan W, Barnes MJ, Kastin AJ. Leptin receptor mRNA in rat brain astrocytes. Peptides (2009) 30:2275-80. doi:10.1016/j.peptides.2009.08.023

96. Kim JG, Suyama S, Koch M, Jin S, Argente-Arizon P, Argente J, et al. Leptin signaling in astrocytes regulates hypothalamic neuronal circuits and feeding. Nat Neurosci (2014) 17:908-10. doi:10.1038/nn.3725

97. Guillod-Maximin E, Lorsignol A, Alquier T, Penicaud L. Acute intracarotid glucose injection towards the brain induces specific c-fos activation in hypothalamic nuclei: involvement of astrocytes in cerebral glucose-sensing in rats. J Neuroendocrinol (2004) 16:464-71. doi:10.1111/j.1365-2826.2004.01185.x

98. Marty N, Dallaporta M, Foretz M, Emery M, Tarussio D, Bady I, et al. Regulation of glucagon secretion by glucose transporter type 2 (glut2) and astrocyte-dependent glucose sensors. J Clin Invest (2005) 115:3545-53. doi:10.1172/JCI26309

99. McDougal DH, Hermann GE, Rogers RC. Astrocytes in the nucleus of the solitary tract are activated by low glucose or glucoprivation: evidence for glial involvement in glucose homeostasis. Front Neurosci (2013) 7:249. doi:10.3389/fnins.2013.00249

100. McDougal DH, Viard E, Hermann GE, Rogers RC. Astrocytes in the hindbrain detect glucoprivation and regulate gastric motility. Auton Neurosci (2013) 175:61-9. doi:10.1016/j.autneu.2012.12.006

101. Fuente-Martin E, Garcia-Caceres C, Granado M, De Ceballos ML, SanchezGarrido MA, Sarman B, et al. Leptin regulates glutamate and glucose transporters in hypothalamic astrocytes. J Clin Invest (2012) 122:3900-13. doi:10.1172/JCI64102

102. Buckman LB, Thompson MM, Lippert RN, Blackwell TS, Yull FE, Ellacott $\mathrm{KL}$. Evidence for a novel functional role of astrocytes in the acute homeostatic response to high-fat diet intake in mice. Mol Metab (2015) 4:58-63. doi:10.1016/j.molmet.2014.10.001

103. Araque A, Parpura V, Sanzgiri RP, Haydon PG. Tripartite synapses: glia, the unacknowledged partner. Trends Neurosci (1999) 22:208-15. doi:10.1016/ S0166-2236(98)01349-6

104. Araque A, Carmignoto G, Haydon PG, Oliet SH, Robitaille R, Volterra A. Gliotransmitters travel in time and space. Neuron (2014) 81:728-39. doi:10.1016/j.neuron.2014.02.007

105. Haam J, Halmos KC, Di S, Tasker JG. Nutritional state-dependent ghrelin activation of vasopressin neurons via retrograde trans-neuronal-glial stimulation of excitatory GABA circuits. J Neurosci (2014) 34:6201-13. doi:10.1523/JNEUROSCI.3178-13.2014

106. Yang L, Qi Y, Yang Y. Astrocytes control food intake by inhibiting AGRP neuron activity via adenosine A1 receptors. Cell Rep (2015) 11:798-807. doi:10.1016/j.celrep.2015.04.002
107. Shen L, Tso P, Woods SC, Clegg DJ, Barber KL, Carey K, et al. Brain apolipoprotein E: an important regulator of food intake in rats. Diabetes (2008) 57:2092-8. doi:10.2337/db08-0291

108. Oliet SH, Piet R, Poulain DA. Control of glutamate clearance and synaptic efficacy by glial coverage of neurons. Science (2001) 292:923-6. doi:10.1126/ science.1059162

109. Oliet SH. Functional consequences of morphological neuroglial changes in the magnocellular nuclei of the hypothalamus. J Neuroendocrinol (2002) 14:241-6. doi:10.1046/j.0007-1331.2001.00766.x

110. Theodosis DT, Poulain DA, Oliet SH. Activity-dependent structural and functional plasticity of astrocyte-neuron interactions. Physiol Rev (2008) 88:983-1008. doi:10.1152/physrev.00036.2007

111. Bernardinelli Y, Randall J, Janett E, Nikonenko I, Konig S, Jones EV, et al. Activity-dependent structural plasticity of perisynaptic astrocytic domains promotes excitatory synapse stability. Curr Biol (2014) 24:1679-88. doi:10.1016/j.cub.2014.06.025

112. Garcia-Caceres C, Fuente-Martin E, Burgos-Ramos E, Granado M, Frago LM, Barrios V, et al. Differential acute and chronic effects of leptin on hypothalamic astrocyte morphology and synaptic protein levels. Endocrinology (2011) 152:1809-18. doi:10.1210/en.2010-1252

113. Horvath TL, Sarman B, Garcia-Caceres C, Enriori PJ, Sotonyi P, Shanabrough $\mathrm{M}$, et al. Synaptic input organization of the melanocortin system predicts diet-induced hypothalamic reactive gliosis and obesity. Proc Natl Acad Sci U $S$ A (2010) 107:14875-80. doi:10.1073/pnas.1004282107

114. Gouaze A, Brenachot X, Rigault C, Krezymon A, Rauch C, Nedelec E, et al. Cerebral cell renewal in adult mice controls the onset of obesity. PLoS One (2013) 8:e72029. doi:10.1371/journal.pone.0072029

115. Ziotopoulou M, Mantzoros CS, Hileman SM, Flier JS. Differential expression of hypothalamic neuropeptides in the early phase of diet-induced obesity in mice. Am J Physiol Endocrinol Metab (2000) 279:E838-45.

116. Koch M, Varela L, Kim JG, Kim JD, Hernandez-Nuno F, Simonds SE, et al. Hypothalamic POMC neurons promote cannabinoid-induced feeding. Nature (2015) 519:45-50. doi:10.1038/nature14260

117. Labouebe G, Liu S, Dias C, Zou H, Wong JC, Karunakaran S, et al. Insulin induces long-term depression of ventral tegmental area dopamine neurons via endocannabinoids. Nat Neurosci (2013) 16:300-8. doi:10.1038/nn.3321

118. Baroncini M, Jissendi P, Catteau-Jonard S, Dewailly D, Pruvo JP, Francke JP, et al. Sex steroid hormones-related structural plasticity in the human hypothalamus. Neuroimage (2010) 50:428-33. doi:10.1016/j. neuroimage.2009.11.074

119. Locke AE, Kahali B, Berndt SI, Justice AE, Pers TH, Day FR, et al. Genetic studies of body mass index yield new insights for obesity biology. Nature (2015) 518:197-206. doi:10.1038/nature14177

Conflict of Interest Statement: The authors declare that the research was conducted in the absence of any commercial or financial relationships that could be construed as a potential conflict of interest.

Copyright (c) 2015 Nuzzaci, Laderrière, Lemoine, Nédélec, Pénicaud, Rigault and Benani. This is an open-access article distributed under the terms of the Creative Commons Attribution License (CC BY). The use, distribution or reproduction in other forums is permitted, provided the original author(s) or licensor are credited and that the original publication in this journal is cited, in accordance with accepted academic practice. No use, distribution or reproduction is permitted which does not comply with these terms. 